\title{
EFFECT OF CAYENNE PEPPER ADDITION ON PHYSICOCHEMICAL, MICROBIOLOGICAL AND SENSORY PROPERTIES OF DRINKABLE YOGHURT-AYRAN
}

\author{
- Research paper - \\ Furkan AKCAY*, Aysegul BESIR**, Fehmi YAZICI**1 \\ * Duycan Food, Samsun, Turkey \\ **Food Engineering, Engineering Faculty, Ondokuz Mayis University, Samsun, Turkey
}

\begin{abstract}
Cayenne peppers (Capsicum annuum L.) were incorporated to ayran aiming to obtain a health promoting ayran with different flavour. The effects on the physico-chemical characteristics, antioxidant and phenolic capacity, counts of Streptococcus, Lactobacillus, yeast, moulds and coliforms, sensory and volatile compounds analysis were performed. Ayran samples with powdered peppers had significantly higher antioxidant and total phenolic contents than the ayrans with sliced pepper. Pepper addition increased Lactobacillus and Streptococcus counts compared to control ayrans. The dominant bacteria during the storage period (7.61-8.88 log CFU/ml) was Streptococcus. Panelists rated flavour, texture, appearance and color properties of ayran samples with sliced pepper similar to control samples. Ayran samples with $15 \%$ sliced peppers had the maximum overall scores.
\end{abstract}

Keywords: Ayran; yoghurt drink; cayenne pepper (Capsicum annuum L.); traditional beverage; spicy

\section{INTRODUCTION}

Consumers are interested in the production of foods that are rich in nutrients as well as having positive effects on human health. Dairy products are more attractive to consumers because of their positive effects on health compared to carbonated beverages. Fermented dairy products had an increased interest as a result of their nutritional quality and attractiveness (Erkaya et al., 2015). Ayran, refreshing and drinkable fermented dairy product, has commonly been consumed in most countries in the world, especially in Asia and the Middle East, comprising Turkey. Ayran as of a fermented dairy product is the second most widespread consumed and liked product after yoghurt in Turkey. It is traditionally prepared by diluting yoghurt with water at a level of $30-50 \%$ (Köksoy et al., 2003); it is also be industrially produced by the fermentation of the milk standardized to $8 \%$ dry matter content, the addition of yoghurt starter culture and table salt at a maximum level of $1 \%$. Although plain ayran as a national dairy beverage has several advantages like better nutritional value, easy digestion, refreshing

Received: 15.01.2020.

Accepted in revised form: 21.04.2020

${ }^{1}$ Corresponding author. E-Mail address: yazicifehmi@gmail.com effect, and satisfying thirstiness, the preference of consumer turns toward carbonated beverages at restaurant and hotels during the summer compared to fermented dairy beverages. It may be important to widespread ayran consumption by diversifying ayran products like pepper added ayran since the promotion of various fruit flavoured yoghurts significantly contributed to yoghurt consumption of all ages.

Pepper fruit (Capsicum annuum L.) is grown worldwide and consumed fresh or in dried form as food additives, flavouring agent to deliver a hot and pungent aroma ( $\mathrm{Lu}$ et al., 2017). Phenols, flavonoids, and capsaicinoids (Loizzo et al., 2015), vitamins $\mathrm{C}$ and $\mathrm{E}$ as well as provitamin $\mathrm{A}$ and carotenoids (Materska et al., 2005) are a good source of various health-promoting compounds in peppers.

There is no research about fruit-added ayrans in the literature, except the studies mentioning with the properties of health, technological, physicochemical, organoleptic, and microbiological of fruit-added yoghurt. Consequently, the main objective of this research is to examine the effects of Cayenne pepper addition on the compositional, physicochemical and organoleptic, microbiological and functional properties of ayrans during the storage time. 


\section{MATERIAL AND METHODS}

Cow milk was provided by Samsut to produce ayran samples in Samsun, Turkey. Cayenne peppers were purchased from Metro market (Samsun, Turkey). DVS starter cultures YFL350 (Streptococcus thermophilus and Lactobacillus delbrueckii subsp. bulgaricus) for ayran production were kindly provided by Maysa Gida (Istanbul, Turkey).

\section{Ayran production}

The cow's milk $(12.75 \%$ total solids and $4.03 \%$ fat) standardized to $8 \%$ total solids and $1.5 \%$ fat was used to produce ayran samples. After the standardization, homogenization was conducted at $55{ }^{\circ} \mathrm{C}$ under $200 \mathrm{~kg} / \mathrm{cm}^{2}$ pressure. After the pasteurization at $90{ }^{\circ} \mathrm{C}$ for $5 \mathrm{~min}$, the milk was cooled $\left(43-45^{\circ} \mathrm{C}\right)$, inoculated with $10 \mathrm{u} / 1$ ton of YFL350 culture and then incubated until the $\mathrm{pH}$ fell to 4.3. Ayran samples were then cooled down $\left(10{ }^{\circ} \mathrm{C}\right)$ and salt at a concentration of $0.5 \%$ in the final product was added to each sample. Samples were mixed thoroughly and filled into $1000 \mathrm{ml}$ of cups and stored at $4{ }^{\circ} \mathrm{C}$. To prepare ayrans with sliced peppers, the red peppers were cleaned from their stems and seeds and sliced into two pieces longitudinally about $5 \mathrm{~mm}$ thick. Then, the sliced peppers were added to ayran samples at 5, 10 and $15 \%$ concentrations after the salt addition step. Sliced peppers - added ayran samples were transferred to $1 \mathrm{~L}$ sterile glass bottle and kept in refrigerator for 24 hours. Ayran samples were then passed through a stainless steel strainer $(25 \mathrm{~cm} \times 7$ $\mathrm{cm})$ to remove the sliced peppers. The sieved ayran samples were kept at $3-5^{\circ} \mathrm{C}$ for 20 days.

For the ayrans with powdered peppers, the sliced peppers were pre-dried at $60{ }^{\circ} \mathrm{C}$ for three hours in a conventional oven and then samples were transferred to a microwave oven with rotary table operated at a power level of 900 Watt for 15 minutes. The microwave dried peppers were milled at $2000 \mathrm{rpm}$ by an electrical grinder and passed through a $0.5 \mathrm{~mm}$ open sieve. The powdered peppers were then added to ayran at $0.5,1,2.5 \%$ concentrations after the salt addition step.

\section{Physicochemical analyses}

$\mathrm{pH}$, titratable acidity, total solids, fat, protein and ash were determined according to the methods described by Bradly et al. (1992). Viscosity values (cP) of ayran samples were determined by a viscometer (Model DV-1+; Brookfield Engineering Laboratories, Inc., MA, USA). Viscosity measurements for ayran samples with temperature set to $15^{\circ} \mathrm{C}$ taken in $250 \mathrm{ml}$ beakers were carried out at $30 \mathrm{rpm}$ using spindle no 3 as cP after a 30 -second rotation.

\section{Microbiological analyses}

M17 agar (Oxoid Ltd., UK) was used to count Streptococcus and plates were aerobically incubated at $30{ }^{\circ} \mathrm{C}$ for 5 days. MRS agar (Oxoid Ltd., UK) was used to count Lactobacillus incubating the plates at $30{ }^{\circ} \mathrm{C}$ for 5 days. Total yeast and molds were enumerated at $30^{\circ} \mathrm{C}$ for $3-5$ days by using Yeast Extract Glucose Chloramphenicol Agar (YGC) (acidified with 10\% lactic acid. Violet red bile agar (VRB) was used for coliform analysis. The incubation was carried out at $37^{\circ} \mathrm{C}$ for 24 hours (Erkaya et al., 2015).

\section{Bioactive compound extraction}

Ayran extracts were prepared according to Demirci et al. (2017). Briefly, each Ayran sample $(2 \mathrm{ml})$ was mixed with a appropriate amount $(8 \mathrm{ml})$ of methanol (80:20, methanol: distilled water) and centrifuged at $7200 \mathrm{rpm}$ for $10 \mathrm{~min}$ at $4^{\circ} \mathrm{C}$. The supernatant was filtered and stored at $4{ }^{\circ} \mathrm{C}$ for DPPH and TPC analysis.

\section{Total phenolic content assay (TPC)}

The procedure by Singleton et al. (1965) was followed for TPC. Briefly, $0.5 \mathrm{ml}$ of phenolic extract was mixed with $2.5 \mathrm{ml}$ of Folin Ciocelteau's phenol reagent $(0.2 \mathrm{~N})$ and $2 \mathrm{ml}$ $\mathrm{Na}_{2} \mathrm{CO}_{3}(7.5 \%)$ was added within 3 minutes. After 30 minutes of the incubation in dark conditions, absorbance was measured at $760 \mathrm{~nm}$ using a UV/VIS spectrophotometer (Shimadzu UV-1800, Japan). Total phenolic content (TPC) was calculated as $\mu \mathrm{g}$ gallic acid equivalents (GAE) per gram of sample using the calibration curve $\left(\mathrm{R}^{2}=\right.$ $0.998)$ in Eq.1.

$\operatorname{TPC}(\mu \mathrm{g} / \mathrm{ml})=[$ Absorbance -0.0179$) / 0.0123] x$

Dilution Factor

\section{Determination of DPPH free radical scavenging activity}

To determine the DPPH free radical scavenging activity of the extracts, the method described by Behrad et al. (2009) was followed with some modifications. An amount of $0.1 \mathrm{ml}$ supernatant was mixed with $4.9 \mathrm{ml}$ DPPH solution $\left(6.1 \times 10^{-}\right.$ ${ }^{5} \mathrm{M}$ in methanol). The absorbance was measured at $517 \mathrm{~nm}$ by a spectrophotometer (Thermo Fisher, G10S UV-Vis, USA) after 30 minutes of incubation in a dark room at room temperature. The results were expressed according to Eq.2.

$A R A(\%)=\left(\left(A_{c}-A_{s}\right) / A_{c}\right) \times 100$

Antiradical activity as ARA (\%), control (methanol) absorbance as $A_{c}$ and sample 
absorbance as $A_{s}$. Results were calculated as Trolox equivalent and expressed as $\mu \mathrm{M}$ Trolox equivalents (TE) per gram of sample (calibration curve linearity range: $\mathrm{R}^{2}=0.999$ ).

\section{Sensorial analysis}

The sensory properties of ayrans were organoleptically evaluated by using the modified method of William E. S et al. (1970) with maximum scores of 10 for appearance and colour, flavour and general acceptability and 5 for body and texture. Ayran samples in $150 \mathrm{~mL}$ plastic cups with three-digit random numbers were randomly presented to 15 sensory panelists selected from Department of Food Engineering at Ondokuz
Mayis University. The evaluations were carried out after the first and $20^{\text {th }}$ days of storage at $3-5^{\circ} \mathrm{C}$.

\section{Volatile aromatic compound}

Analyses of volatile aromatic compounds were carried out at days 1 and 20 of storage time according to Temiz et al. (2017). Results were calculated as percentage of total volatile aroma compounds.

\section{Statistical analysis}

Statistical analysis of data was done by one-way and three factors randomized complete block design using IBM SPSS software (Version 21, Chicago, USA). Tukey's post-hoc test at the 5\% level of significance was conducted.

\section{RESULTS AND DISCUSSIONS}

\section{Effect of pepper addition on composition}

The milk used for the ayran production had $12.4 \%$ total solids, $3.7 \%$ fat, $3.1 \%$ protein, and $6.50 \mathrm{pH}$ and pepper had $5.5 \mathrm{pH}, 3.6 \%$ fat, $8.38 \%$ total solids, $4.88 \log \mathrm{CFU} / \mathrm{mL}$ yeast and moulds count. Table 1 shows total solids, fat and protein contents of ayrans. The total solid contents of all ayrans were between $7.21 \%-8.55 \%$. Total solid of ayrans with powdered peppers were significantly higher than that of sliced pepper - added and control samples. The increase in sliced pepper concentration did not increase total solid properties and gave similar results as with control samples. This result was expected because the sliced peppers were removed during the production, but powdered peppers were left within ayran.

In our study, ayran samples had the fat ratio between 1.8-2.87\%. Pepper addition significantly affected the fat contents of ayrans $(\mathrm{p}<0.05)$. Fat contents of ayrans with powdered peppers were significantly higher than that of sliced pepperadded and control samples. The mean fat ratio in the ayrans with peppers was similar to those previously reported by Köksoy and Kilıç (2003). The effect of pepper form and concentration did not significantly affect the protein contents of ayrans ( $p>0.05$ ).

\section{Effect of storage time on physicochemical and functional properties of Ayrans}

The effect of pepper form and concentration level on the $\mathrm{pH}$, viscosity, DPPH and TPC values of ayrans during storage is shown in Table 2. The $\mathrm{pH}$ values of ayrans did not change until the $10^{\text {th }}$ day of storage $(\mathrm{p}>0.05)$ and then significantly declined at the $20^{\text {th }}$ storage day $(\mathrm{p}<0.05)$. The concentration of each sliced and powdered peppers was not significantly affected by the $\mathrm{pH}$ values of the samples $(\mathrm{p}>0.05)$. The mean $\mathrm{pH}$ values of the ayrans with pepper added were similar to the those stated by Köksoy and Kılıç (2003) and Ozturkoglu-Budak et al. (2016). Twenty days of storage decreased the $\mathrm{pH}$ of ayrans to lower $\mathrm{pH}$ values (4.34-3.47) possibly as a result of accumulation of lactic acid.

Viscosity values of the ayrans with sliced and powdered peppers were significantly different $(\mathrm{p}<0.05)$. Samples with $10 \%$ sliced and $2.5 \%$ powdered peppers had the highest viscosity, while control samples had the lowest. While storage period, viscosity values of the ayrans significantly increased $(\mathrm{p}<0.05)$. Lopez-Hernandez et al. (1996) reported that Capsicum annuum L. contained 0.73 $\mathrm{g}$ pectin/ $100 \mathrm{~g}$ fresh fruit. The increase in the viscosity values of the ayrans with pepper while storage period may be related the pectin content of the peppers. Parallel to our findings, TamucayOzunlu (2005) found viscosity values of ayrans between 54 and $175 \mathrm{cP}$.

Since pepper includes complex phenolic compounds (Materska \& Perucka, 2005), the samples with peppers had higher phenolic contents and antioxidant activity than control samples. The ayran samples with powdered peppers had significantly higher antioxidant and total phenolic contents $(p<0.05)$ than the ayrans with sliced pepper, but ayrans with sliced peppers and control ayrans were similar $(\mathrm{p}>0.05)$. Ayrans with $2.5 \%$ powdered peppers had the maximum total phenolic content and radical scavenging activity. Phenolic and antioxidant capacity generally decline day by day. But an increase in TPC and DPPH radical scavenging activity was observed for all ayran samples throughout the storage period. 
Table 1. Fat, protein and total solid (\%) contents of ayrans

\begin{tabular}{ccccc}
\hline Pepper type & $\begin{array}{c}\text { Pepper } \\
\text { concentration (\%) }\end{array}$ & Total solids (\%) & Protein (\%) & Fat (\%) \\
\hline Control & 0 & $7.36 \pm 0.16^{\mathrm{c}}$ & $2.87 \pm 0.01^{\mathrm{a}}$ & $1.80 \pm 0.05^{\mathrm{d}}$ \\
\hline \multirow{3}{*}{ Sliced } & 5 & $7.31 \pm 0.14^{\mathrm{c}}$ & $2.84 \pm 0.03^{\mathrm{a}}$ & $1.90 \pm 0.11^{\mathrm{d}}$ \\
& 10 & $7.41 \pm 0.24^{\mathrm{c}}$ & $2.86 \pm 0.01^{\mathrm{a}}$ & $1.93 \pm 0.19^{\mathrm{cd}}$ \\
\multirow{3}{*}{ Powder } & 15 & $7.42 \pm 0.26^{\mathrm{c}}$ & $2.86 \pm 0.01^{\mathrm{a}}$ & $2.06 \pm 0.27^{\mathrm{cd}}$ \\
& 0.5 & $7.81 \pm 0.54^{\mathrm{bc}}$ & $2.86 \pm 0.02^{\mathrm{a}}$ & $2.27 \pm 0.19^{\mathrm{bc}}$ \\
& 1 & $8.38 \pm 0.62^{\mathrm{ab}}$ & $2.87 \pm 0.03^{\mathrm{a}}$ & $2.60 \pm 0.27^{\mathrm{ab}}$ \\
\hline
\end{tabular}

a-c: Means followed by the same letters with in the same column are not significant at $\mathrm{p}>0.05$.

Table 2. Physicochemical properties of ayrans during storage

\begin{tabular}{|c|c|c|c|c|c|}
\hline \multirow[t]{2}{*}{ Analysis } & \multirow{2}{*}{$\begin{array}{l}\text { Pepper } \\
\text { form }\end{array}$} & \multirow{2}{*}{$\begin{array}{c}\text { Added } \\
\text { pepper } \\
(\%)\end{array}$} & \multicolumn{3}{|c|}{ Storage time (day) } \\
\hline & & & 1 & 10 & 20 \\
\hline \multirow[t]{7}{*}{ pH } & Control & 0 & $4.32 \pm 0.22^{\mathrm{Aa}}$ & $4.29 \pm 0.03^{\mathrm{Aa}}$ & $3.70 \pm 0.08^{\mathrm{Ab}}$ \\
\hline & \multirow{3}{*}{ Sliced } & 5 & $4.32 \pm 0.04^{\mathrm{Aa}}$ & $4.30 \pm 0.02^{\mathrm{Aa}}$ & $3.72 \pm 0.07^{\mathrm{Ab}}$ \\
\hline & & 10 & $4.32 \pm 0.03^{\mathrm{Aa}}$ & $4.31 \pm 0.02^{\mathrm{Aa}}$ & $3.71 \pm 0.08^{\mathrm{Ab}}$ \\
\hline & & 15 & $4.33 \pm 0.02^{\mathrm{Aa}}$ & $4.31 \pm 0.01^{\mathrm{Aa}}$ & $3.71 \pm 0.09^{\mathrm{Ab}}$ \\
\hline & \multirow{3}{*}{ Powder } & 0.5 & $4.33 \pm 0.03^{\mathrm{Aa}}$ & $4.29 \pm 0.06^{\mathrm{Aa}}$ & $3.55 \pm 0.35^{\mathrm{Ab}}$ \\
\hline & & 1 & $4.33 \pm 0.05^{\mathrm{Aa}}$ & $4.28 \pm 0.06^{\mathrm{Aa}}$ & $3.51 \pm 0.37^{\mathrm{Ab}}$ \\
\hline & & 2.5 & $4.34 \pm 0.06^{\mathrm{Aa}}$ & $4.28 \pm 0.07^{\mathrm{Aa}}$ & $3.47 \pm 0.45^{\mathrm{Ab}}$ \\
\hline \multirow{7}{*}{ 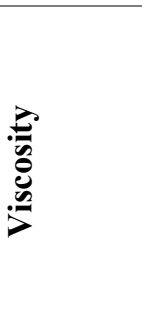 } & Control & 0 & $36.00 \pm 1.41^{\mathrm{Cb}}$ & $40.50 \pm 0.71^{\mathrm{Da}}$ & $42.50 \pm 0.71^{\mathrm{Fa}}$ \\
\hline & \multirow{3}{*}{ Sliced } & 5 & $40.00 \pm 0.00^{\mathrm{BCc}}$ & $43.00 \pm 0.00^{\mathrm{CDb}}$ & $48.00 \pm 1.41^{\mathrm{DEa}}$ \\
\hline & & 10 & $44.00 \pm 4.24^{\mathrm{Ba}}$ & $45.00 \pm 0.00^{\mathrm{CDa}}$ & $46.50 \pm 0.71^{\mathrm{Ea}}$ \\
\hline & & 15 & $45.50 \pm 6.36^{\mathrm{Ba}}$ & $46.70 \pm 3.53^{\mathrm{Ca}}$ & $50.00 \pm 0.00^{\mathrm{Da}}$ \\
\hline & \multirow{3}{*}{ Powder } & 0.5 & $66.50 \pm 0.71^{\mathrm{Ab}}$ & $67.50 \pm 0.71^{\mathrm{Bb}}$ & $70.00 \pm 0.00^{\mathrm{Ca}}$ \\
\hline & & 1 & $67.00 \pm 0.00^{\mathrm{Ab}}$ & $72.50 \pm 3.53^{\text {Aab }}$ & $78.00 \pm 0.00^{\mathrm{Ba}}$ \\
\hline & & 2.5 & $69.50 \pm 0.71^{\mathrm{Ac}}$ & $75.50 \pm 0.71^{\mathrm{Ab}}$ & $80.50 \pm 0.71^{\mathrm{Aa}}$ \\
\hline \multirow{7}{*}{ 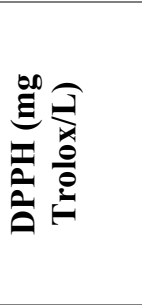 } & Control & 0 & $140.08 \pm 0.32^{\mathrm{Bb}}$ & $151.53 \pm 0.19^{\mathrm{Cb}}$ & $272.42 \pm 0.06^{\mathrm{EFa}}$ \\
\hline & \multirow{3}{*}{ Sliced } & 5 & $140.96 \pm 0.35^{\mathrm{Bc}}$ & $163.67 \pm 0.22^{\mathrm{BCDb}}$ & $276.29 \pm 0.13^{\mathrm{DFa}}$ \\
\hline & & 10 & $143.91 \pm 0.06^{\mathrm{Bc}}$ & $167.65 \pm 0.07^{\mathrm{BCDEb}}$ & $278.38 \pm 0.13^{\mathrm{DFa}}$ \\
\hline & & 15 & $144.69 \pm 0.09^{\mathrm{Bc}}$ & $170.06 \pm 0.46^{\mathrm{BDEb}}$ & $281.52 \pm 0.40^{\mathrm{CDa}}$ \\
\hline & \multirow{3}{*}{ Powder } & 0.5 & $150.68 \pm 0.22^{\mathrm{ABb}}$ & $156.03 \pm 0.33^{\mathrm{BCb}}$ & $287.18 \pm 0.12^{\mathrm{BCa}}$ \\
\hline & & 1 & $153.33 \pm 0.30^{\mathrm{ABc}}$ & $193.19 \pm 0.32^{\mathrm{Ab}}$ & $290.84 \pm 0.14^{\mathrm{Ba}}$ \\
\hline & & 2.5 & $161.78 \pm 0.31^{\mathrm{Ac}}$ & $199.99 \pm 0.04^{\mathrm{Ab}}$ & $311.88 \pm 0.17^{\mathrm{Aa}}$ \\
\hline \multirow{7}{*}{ 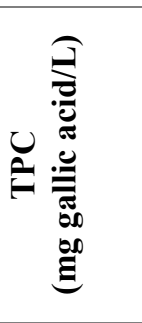 } & Control & 0 & $103.74 \pm 2.22^{\mathrm{Cb}}$ & $109.65 \pm 2.01^{\mathrm{Db}}$ & $131.48 \pm 1.22^{\mathrm{Ca}}$ \\
\hline & \multirow{3}{*}{ Sliced } & 5 & $106.26 \pm 0.57^{\mathrm{Cc}}$ & $113.84 \pm 1.24^{\mathrm{Db}}$ & $131.69 \pm 0.20^{\mathrm{Ca}}$ \\
\hline & & 10 & $110.81 \pm 2.00^{\mathrm{Cb}}$ & $119.19 \pm 1.32^{\mathrm{Db}}$ & $135.27 \pm 0.13^{\mathrm{CDa}}$ \\
\hline & & 15 & $112.82 \pm 0.86^{\mathrm{Cb}}$ & $121.18 \pm 1.09^{\mathrm{Db}}$ & $140.70 \pm 0.48^{\mathrm{Da}}$ \\
\hline & \multirow{3}{*}{ Powder } & 0.5 & $156.15 \pm 0.53^{\mathrm{Cb}}$ & $157.66 \pm 1.01^{\mathrm{Cb}}$ & $171.13 \pm 1.55^{\mathrm{Ba}}$ \\
\hline & & 1 & $161.08 \pm 1.42^{\mathrm{Bb}}$ & $170.73 \pm 1.01^{\mathrm{Bb}}$ & $192.28 \pm 1.56^{\mathrm{Ba}}$ \\
\hline & & 2.5 & $222.23 \pm 1.62^{\mathrm{Ab}}$ & $245.24 \pm 1.22^{\mathrm{Aa}}$ & $245.99 \pm 1.46^{\mathrm{Aa}}$ \\
\hline
\end{tabular}

A-C : Means followed by the same letters with in the same column are not significant at $\mathrm{p}>0.05$. $a-c$ :Means followed by the same letters with in the same row are not significant at $p>0.05$.

Effect of storage time on microbiological properties of Ayrans

Microbiological features of Ayran produced in different cayenne pepper concentrations are shown in Figures 1, 2 and 3. Lactobacillus counts of ayrans with sliced pepper were significantly higher than the ayrans with powdered pepper $(\mathrm{p}<0.05)$ (Figure 1). The average counts of Lactobacillus of control ayrans increased $1.14 \operatorname{logs}$ throughout the storage period that is comparable to the increase in the ayrans with sliced or powdered pepper. This result indicates that the addition of pepper to ayran did not significantly retain the activity of lactic acid bacteria. Our results are higher than some studies reported by Ozturkoglu-Budak et al. (2016) and similar to other (Erkaya et al., 2015). 

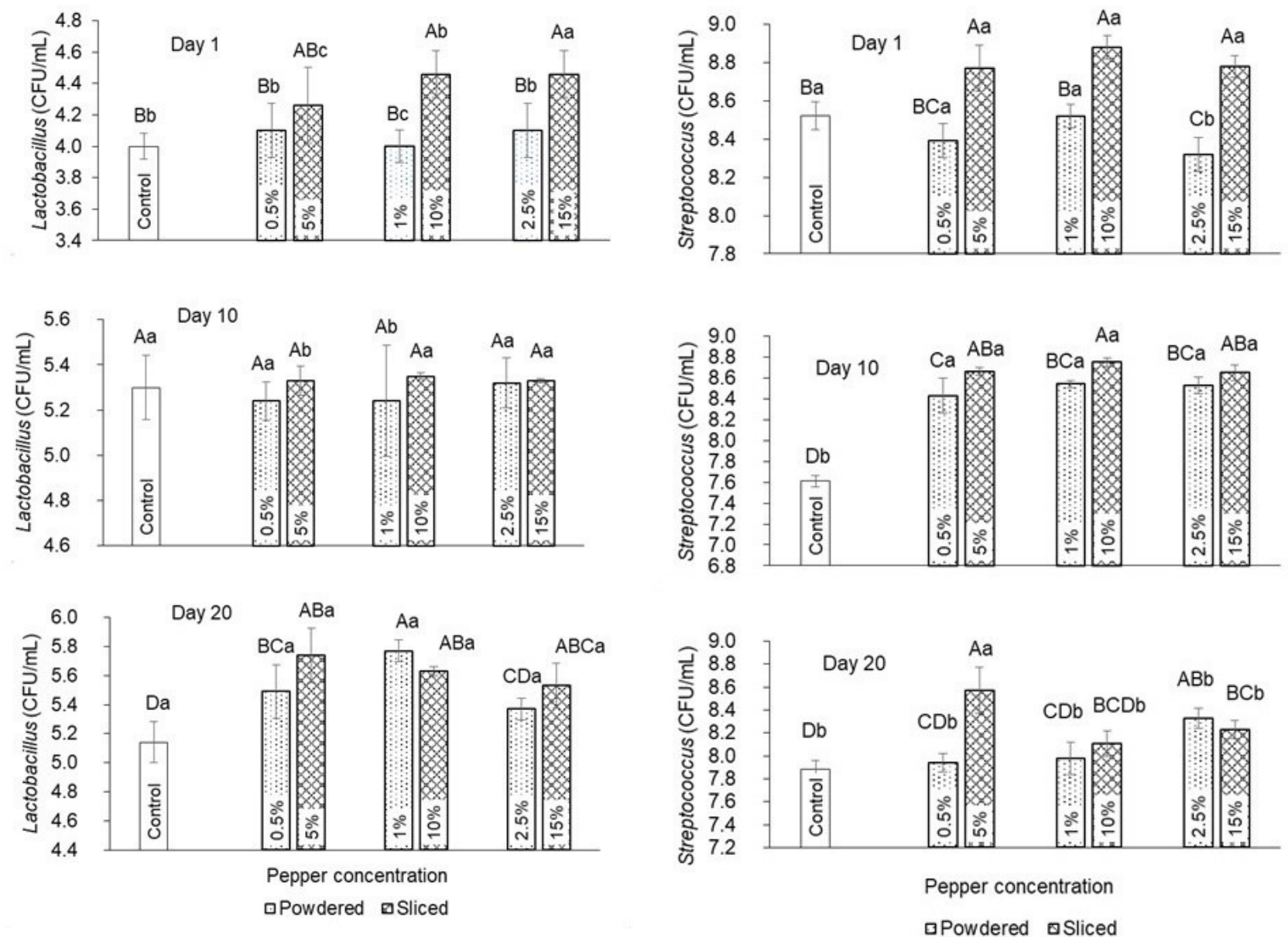

Figure 1. Effect of pepper addition on the Lactobacillus counts of ayrans (Capital letters show the significant difference $(\mathrm{P}<0.05)$ between treatments at the same storage day. Small letters show the significant difference $(\mathrm{P}<0.05)$ between storage days of the same treatment)

The population of Streptococcus increased from 7.61 to $8.88 \log \mathrm{CFU} \mathrm{ml}{ }^{-1}$ in all samples during the storage time (Figure 2). Contrary to the Lactobacillus trend, Streptococcus population significantly decreased from the first day to $20^{\text {th }}$ day of storage $(p<0.05)$. As it is in the case of Lactobacillus counts, more Streptococcus transferred from sliced pepper to ayran compared to powdered pepper. Pepper form added to ayrans did not considerable suppressed the Streptococcus growth throughout the storage period. During storage, the population of Streptococcus was higher than those of Lactobacillus in all ayran samples. The ratio of the mean counts of Streptococcus to Lactobacillus in all Ayran samples was calculated as 1.68 that is within the recommendation limits of $1: 1$ to $2: 1$ (SunWaterhouse et al., 2013).

Yeasts and moulds are microorganisms that play an important role in food spoilage. Total yeasts and

Figure 2. Effect of pepper addition on the Streptococcus counts of ayrans (Capital letters show the significant difference $(\mathrm{P}<0.05)$ between treatments at the same storage day. Small letters show the significant difference $(\mathrm{P}<0.05)$ between storage days of the same treatment)

moulds counts recommended are $<10 \mathrm{CFU} \mathrm{\textrm {g } ^ { - 1 }}$ (Kiros et al., 2016). The population of control samples increased about $1.5 \operatorname{logs}$ compared to about $1 \log$ increase in the samples with pepper added during the storage period (Figure 3). It may be related to the antimicrobial activity of the pepper. One the capsaicin analogues, vanillin has shown inhibitory activity towards the growth of yeast and moulds (Bae et al., 2012).

To assess the microbiological quality and hygienic conditions of the ayran samples, total coliforms and $E$. coli were counted and were not detected in any of the ayran samples during the storage period. Results from microbiological analysis reveal that the addition of Cayenne Pepper to the ayran composition as a plant adjunct did not significantly decline desirable yoghurt bacteria of Streptococcus and Lactobacillus and considerable reduce the yeasts and moulds counts during the storage. 

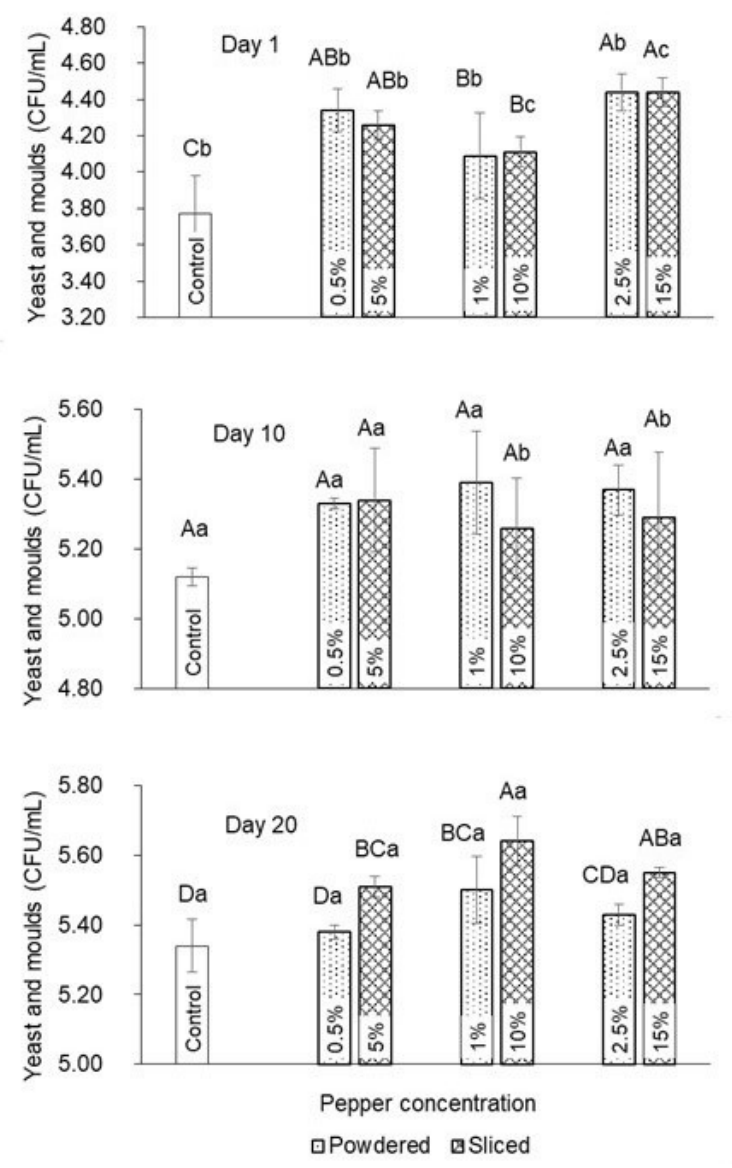

Figure 3. Effect of pepper addition on the yeasts and moulds counts of ayrans (Capital letters show the significant difference $(\mathrm{P}<0.05)$ between treatments at the same storage day. Small letters show the significant difference $(\mathrm{P}<0.05)$ between storage days of the same treatment)

\section{Effect of storage time on sensory properties of Ayrans}

Sensory evaluation values of pepper-added ayrans are shown in Table 3. Panelists found that the ayrans with powdered pepper at all concentrations lacked the optimum ayran appearance and color because the samples were too dark and red. Since sliced peppers were removed from ayran formula after the fermentation step, panelists did not offense the appearance and colour and other sensory properties. All ayran samples with sliced pepper took higher body and texture scores than control ayrans $(p<0.05)$; ayrans with powdered pepper were criticized for being too weak, wheyoff, and broken body, especially at $2.5 \%$ concentration. As in the case of flavour, sliced pepper-added samples took higher general acceptability scores than powdered pepper-added samples $(p<0.05)$; the samples with $\% 15$ sliced pepper received the highest score among all samples.

\section{Volatile compounds of ayran}

The percentage of acids, terpenes, aldehydes, esters, alcohols and ketones on total volatiles varied between 9.86-77.33\%, 2.31-10.02\%, 0.47$12.12 \%, 1.08-25.97 \%, 0.46-30.73 \%$ and $2.75-$ $61.36 \%$, respectively (Figure 4). During storage, the acid content of the control and powdered pepper-added samples did not change significantly $(p<0.05)$ while the slice pepper-added samples decreased. The dominant acids found in all samples are octanoic, hexanoic, decanoic, benzoic and acetic acid. Benzene, styrene and limonene were detected in all samples. In addition, linalool was also detected in pepper added ayran. The linalool, found in Capsicum annum by Korkmaz et al.(2017), contributes to the sweet caramel and fresh flowery aroma, commonly found in many fruits, vegetables and food aroma (Mazida et al., 2005).

Aldehyde content was decreased during storage in all samples. Hexanal, nonanal, octanal and acetaldehyde were found as the main aldehydes in all samples as main aldehydes. Safranal, 3methylbutanal and 2-octenal were also detected in pepper added ayran. These aldehydes were also reported in red bell peppers by van Ruth et al. (2003).

Acetic acid ethyl ester and acetic acid hexyl ester, hexanoic acid ethyl ester, octanoic acid ethyl ester, hexanoic acid methyl ester and octanoic acid methyl ester were found in all ayran samples. These esters were found in researches with yogurt and pepper (Korkmaz et al., 2017). Ethanol, 2ethyl hexanol, 1-pentanol, 1-octanol, hexanol, 2(2-Ethoxyethoxy) ethanol were dominant alcohols in all samples. In addition to these alcohols, 2-ethyl hexanol and 1-octen 3-ol and methanol were detected in pepper added ayrans. Acetoin, acetone, 2-octanone, heptan-2-one, 3-methyl-2-butanone, diacetyl, 2-nonanone were identified in all ayran samples. 
Table 3. Effect of pepper addition on sensory properties of ayrans during storage

\begin{tabular}{|c|c|c|c|c|}
\hline \multirow{2}{*}{ Analysis } & \multirow{2}{*}{ Pepper form } & \multirow{2}{*}{$\begin{array}{c}\text { Added pepper } \\
(\%)\end{array}$} & \multicolumn{2}{|c|}{ Storage time (day) } \\
\hline & & & 1 & 20 \\
\hline \multirow{7}{*}{$\begin{array}{c}\text { Appearance and } \\
\text { colour }\end{array}$} & Control & 0 & $9.00 \pm 0.000^{\mathrm{Aa}}$ & $9.00 \pm 1.414^{\mathrm{Aa}}$ \\
\hline & \multirow{3}{*}{ Sliced } & 5 & $9.50 \pm 0.707^{\mathrm{Aa}}$ & $9.00 \pm 1.414^{\mathrm{Ab}}$ \\
\hline & & 10 & $9.00 \pm 1.414^{\mathrm{Aa}}$ & $9.00 \pm 0.707^{\mathrm{Aa}}$ \\
\hline & & 15 & $9.00 \pm 0.354^{\mathrm{Aa}}$ & $8.00 \pm 0.000^{\mathrm{ABb}}$ \\
\hline & \multirow{3}{*}{ Powder } & 0.5 & $7.00 \pm 0.000^{\mathrm{Ba}}$ & $6.00 \pm 0.707^{\mathrm{BCb}}$ \\
\hline & & 1 & $4.50 \pm 0.354^{\mathrm{Ca}}$ & $4.00 \pm 0.269^{\mathrm{Cb}}$ \\
\hline & & 2.5 & $3.00 \pm 0.354^{\mathrm{Ca}}$ & $2.00 \pm 0.000^{\mathrm{Db}}$ \\
\hline \multirow{7}{*}{ Flavour } & Control & 0 & $8.00 \pm 0.000^{\mathrm{Aa}}$ & $7.00 \pm 0.000^{\mathrm{Bb}}$ \\
\hline & \multirow{3}{*}{ Sliced } & 5 & $7.13 \pm 0.177^{\mathrm{Bb}}$ & $7.63 \pm 0.177^{\mathrm{Ba}}$ \\
\hline & & 10 & $7.66 \pm 0.481^{\mathrm{Ba}}$ & $7.32 \pm 0.445^{\mathrm{Bb}}$ \\
\hline & & 15 & $9.19 \pm 0.622^{\mathrm{Aa}}$ & $8.63 \pm 0.177^{\mathrm{Ab}}$ \\
\hline & \multirow{3}{*}{ Powder } & 0.5 & $6.00 \pm 0.707^{\mathrm{Ca}}$ & $4.00 \pm 0.000^{\mathrm{Cb}}$ \\
\hline & & 1 & $4.00 \pm 0.000^{\mathrm{Da}}$ & $3.38 \pm 0.000^{\mathrm{Da}}$ \\
\hline & & 2.5 & $3.50 \pm 0.000^{\mathrm{Da}}$ & $2.75 \pm 0.707^{\mathrm{Db}}$ \\
\hline \multirow{7}{*}{$\begin{array}{l}\text { Body and } \\
\text { texture }\end{array}$} & Control & 0 & $7.86 \pm 0.530^{\mathrm{Ba}}$ & $3.50 \pm 0.000^{\mathrm{Cb}}$ \\
\hline & \multirow{3}{*}{ Sliced } & 5 & $4.5 \pm 0.000^{\mathrm{Aa}}$ & $4.06 \pm 0.177^{\mathrm{Bb}}$ \\
\hline & & 10 & $4.12 \pm 0.354^{\mathrm{ABa}}$ & $4.00 \pm 0.000^{\mathrm{Ba}}$ \\
\hline & & 15 & $4.37 \pm 0.354^{\mathrm{ABb}}$ & $4.53 \pm 0.092^{\mathrm{Aa}}$ \\
\hline & \multirow{3}{*}{ Powder } & 0.5 & $3.50 \pm 0.354^{\mathrm{Ca}}$ & $2.87 \pm 0.707^{\mathrm{Db}}$ \\
\hline & & 1 & $1.69 \pm 0.177^{\mathrm{Da}}$ & $1.50 \pm 0.000^{\mathrm{Eb}}$ \\
\hline & & 2.5 & $1.62 \pm 0.000^{\mathrm{Da}}$ & $0.84 \pm 0.445^{\mathrm{Fb}}$ \\
\hline \multirow{7}{*}{$\begin{array}{c}\text { General } \\
\text { acceptability }\end{array}$} & Control & 0 & $8.00 \pm 0.354^{\mathrm{BCa}}$ & $7.50 \pm 0.354^{\mathrm{BCb}}$ \\
\hline & \multirow{3}{*}{ Sliced } & 5 & $6.50 \pm 0.707^{\mathrm{Db}}$ & $8.00 \pm 0.707^{\mathrm{CDa}}$ \\
\hline & & 10 & $8.50 \pm 0.707^{\mathrm{ABa}}$ & $8.00 \pm 1.414^{\mathrm{ABb}}$ \\
\hline & & 15 & $9.50 \pm 0.707^{\mathrm{ACa}}$ & $9.00 \pm 0.707^{\mathrm{Ab}}$ \\
\hline & \multirow{3}{*}{ Powder } & 0.5 & $7.00 \pm 0.354^{\mathrm{Da}}$ & $5.00 \pm 0.000^{\mathrm{Db}}$ \\
\hline & & 1 & $3.50 \pm 0.707^{\mathrm{Ea}}$ & $3.00 \pm 0.000^{\mathrm{Eb}}$ \\
\hline & & 2.5 & $2.00 \pm 0.000^{\mathrm{F}}$ & $1.50 \pm 0.354^{\mathrm{Eb}}$ \\
\hline
\end{tabular}

A-C : Means followed by the same letters with in the same column are not significant at $\mathrm{p}>0.05$. a-c : Means followed by the same letters with in the same row are not significant at $p>0.05$.

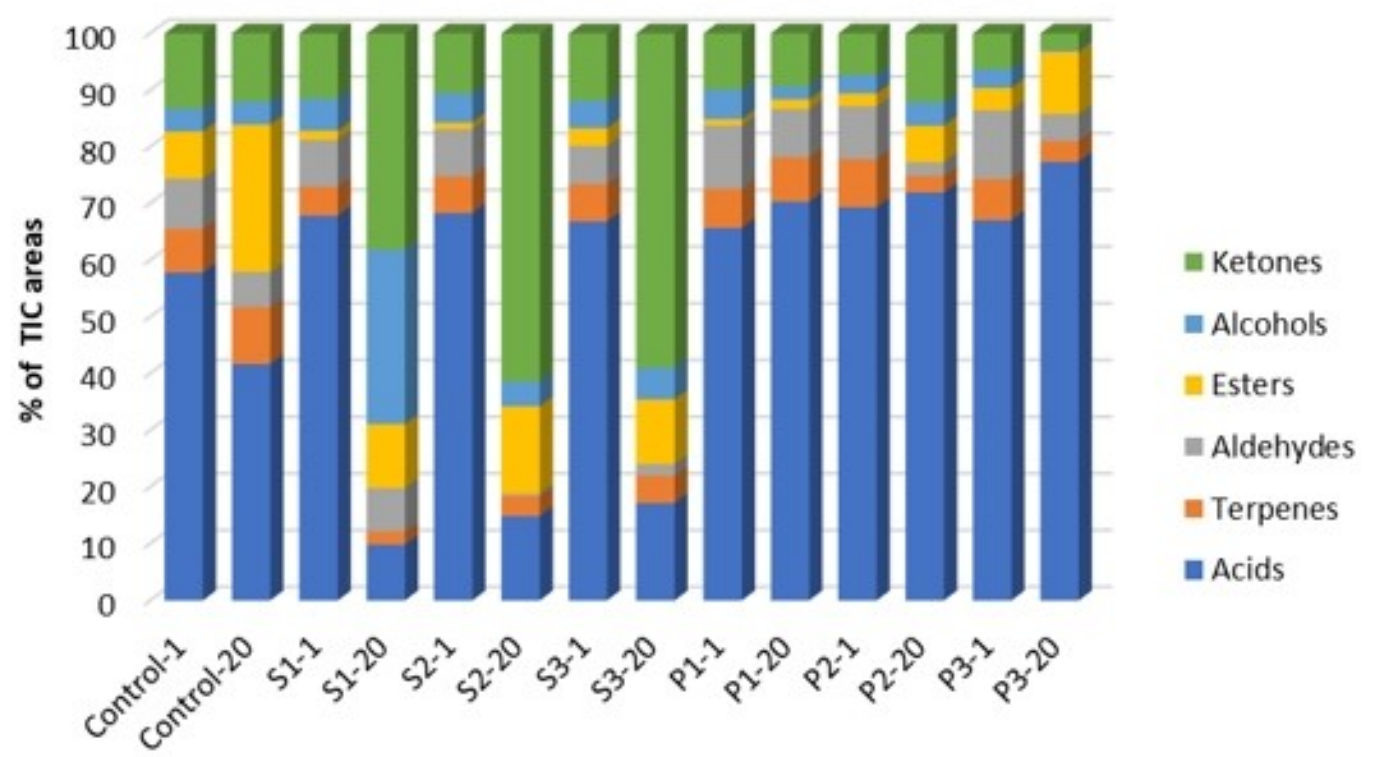

Samples

Figure 4. GC-MS results of the main volatile compounds detected on the 1st and 20th storage days of Ayran samples (S1-S2-S3: Ayran with sliced peppers with 5-10-15\% concentration; P1-P2-P3: Ayran with powdered peppers with $0.5-1-1.5 \%$ concentration, respectively) 


\section{CONCLUSIONS}

This study demonstrated that cayenne pepper was successfully used in ayran production. The form of the pepper used for the ayran production significantly affect the physicochemical, microbiological, and sensory properties of ayrans. The addition of the pepper to ayran formula significantly improved the phenolic content and antioxidant activity of the final product and this effect increased with respect to the control samples throughout the storage period. While the addition of pepper to ayran did not reduce the desired yogurt bacteria of Streptococcus and Lactobacillus counts, it had a suppressive effect on the number of yeasts and molds that played an important role in food spoilage. It is therefore possible to produce a more functional ayran and to maintain its stability until the storage period of 20 days. It can be concluded that cayenne pepper in the form of slice can be added to the ayran formula at a level of 10 to $15 \%$.

\section{ACKNOWLEDGEMENTS}

Authors did not get any financial support for carrying out this research. There is no conflict of interest between authors.

\section{REFERENCES}

1. Bae, H., Jayaprakasha, G. K., Jifon, J., \& Patil, B. S. (2012). Variation of antioxidant activity and the levels of bioactive compounds in lipophilic and hydrophilic extracts from hot pepper (Capsicum spp.) cultivars. Food Chem, 134(4), 1912-1918. doi:10.1016/j.foodchem.2012.03.108

2. Behrad, S., Yusof, M. Y., Goh, K. L., \& Baba, A. S. (2009). Manipulation of Probiotics Fermentation of Yogurt by Cinnamon and Licorice Effects on Yogurt Formation and Inhibition of Helicobacter Pylori Growth in vitro. International Journal of Nutrition and Food Engineering, 3.

3. Bradley, R.L., Arnold, Jr. E., Barbano, Jr. D.M. Semerad, R.G., Smith, D.E. \& Vines, B.K. 1992. Chemical and physical methods. In: R.T. Marshall Eds., Standard methods for the examination of dairy products. American Public Health Association, Washington, DC.

4. Demirci, T., Aktaş, K., Sözeri, D., Öztürk, H. İ., \& Akın, N. (2017). Rice bran improve probiotic viability in yoghurt and provide added antioxidative benefits. Journal of Functional Foods, 36, 396-403. doi:10.1016/j.jff.2017.07.019

5. Erkaya, T., Baslar, M., Sengul, M., \& Ertugay, M. F. (2015). Effect of thermosonication on physicochemical, microbiological and sensorial characteristics of ayran during storage. Ultrason Sonochemistry, 23, 406-412. doi:10.1016/j.ultsonch.2014.08.009

6. Kiros, E., Seifu, E., Bultosa, G., \& Solomon, W. K. (2016). Effect of carrot juice and stabilizer on the physicochemical and microbiological properties of yoghurt. LWT - Food Science and Technology, 69, 191-196. doi:10.1016/j.lwt.2016.01.026

7. Korkmaz, A., Hayaloglu, A. A., \& Atasoy, A. F. (2017). Evaluation of the volatile compounds of fresh ripened Capsicum annuum and its spice pepper (dried red pepper flakes and isot). Lwt-Food Science and Technology, 84, 842-850. doi:10.1016/j.lwt.2017.06.058

8. Köksoy, A., \& Kilıç, M. (2003). Effects of water and salt level on rheological properties of ayran, a Turkish yoghurt drink. International Dairy Journal, 13(10), 835-839. doi:10.1016/s09586946(03)00103-1

9. Loizzo, M. R., Pugliese, A., Bonesi, M., Menichini, F., \& Tundis, R. (2015). Evaluation of chemical profile and antioxidant activity of twenty cultivars from Capsicum annuum, Capsicum baccatum, Capsicum chacoense and Capsicum chinense: A comparison between fresh and processed peppers. $L W T$ - Food Science and Technology, 64(2), 623-631. doi:10.1016/j.lwt.2015.06.042

10. Lopez-Hernandez, J., Oruna-Concha, M. J., Simal-Lozano, J., Vazquez-Blanco, M. E., \& GonzalezCastro, M. J. (1996). Chemical composition of Padron peppers (Capsicum annuum L.) grown in Galicia.

11. Lu, M., Ho, C. T., \& Huang, Q. (2017). Extraction, bioavailability, and bioefficacy of capsaicinoids. $J$ Food Drug Anal, 25(1), 27-36. doi:10.1016/j.jfda.2016.10.023

12. Materska, M., \& Perucka, I. (2005). Antioxidant Activity of the Main Phenolic Compounds Isolated. Journal of Agricultural and Food Chemistry, 53, 1750-1756.

13. Mazida, M. M., Salleh, M. M., \& Osman, H. (2005). Analysis of volatile aroma compounds of fresh chilli (Capsicum annuum) during stages of maturity using solid phase microextraction (SPME). Journal of Food Composition and Analysis, 18(5), 427-437. doi:10.1016/j.jfca.2004.02.001 
14. Ozturkoglu-Budak, S., Akal, C., \& Yetisemiyen, A. (2016). Effect of dried nut fortification on functional, physicochemical, textural, and microbiological properties of yogurt. Journal of Dairy Science, 99(11), 8511-8523. doi:10.3168/jds.2016-11217

15. Singleton, V. L., \& Rossi, J. (1965). Colorimetry of total phenolics with phosphomolybdic phosphotungstic acid reagents. American Journal of Enology and Viticulture, 16, 144-158.

16. Sun-Waterhouse, D., Zhou, J., \& Wadhwa, S. S. (2013). Drinking yoghurts with berry polyphenols added before and after fermentation. Food Control, 32(2), 450-460. doi:10.1016/j.foodcont.2013.01.011

17. Tamucay-Ozunlu, B. (2005). Studies on some parameters affecting the quality of Ayran(Drinking yoghurt).(Doctorate $\mathrm{PhD}$ Thesis), Ankara University.

18. Temiz, H., \& Tarakci, Z. (2017). Composition of volatile aromatic compounds and minerals of tarhana enriched with cherry laurel (Laurocerasus officinalis). Journal of Food Science and TechnologyMysore, 54(3), 735-742. doi:10.1007/s13197-017-2513-z

19. van Ruth, S., Boscaini, E., Mayr, D., Pugh, J., \& Posthumus, M. (2003). Evaluation of three gas chromatography and two direct mass spectrometry techniques for aroma analysis of dried red bell peppers. International Journal of Mass Spectrometry, 223(1-3), 55-65. doi:Pii S1387-3806(02)00780-7. Doi 10.1016/S1387-3806(02)00780-7

20. William E. S, \& Paul R. E. (1970). Microbially induced flavours and fermented foods flavour in fermented dairy products. Journal of Agricultural and Food Chemistry, 18, 557-562. 